dogłębnej analizy urzędu proroka i jego autentyczności, przedstawiając jego formę w chrześcijaństwie przedmontanistycznym oraz przede wszystkim rozumienie tego urzędu w ruchu montanistycznym. Jest to więc w głównej mierze opracowanie próbujące ukazać sposób rozumienia i ustalenia kryteriów ruchu prorockiego w II i III wieku, wskazujące, że to właśnie montanizm ,był prawdziwym końcem epoki proroków chrześcijańskich - ich autorytetu niezależnego od lokalnych ustanowionych biskupów" (s. 88), był swoistym nowym powiewem ducha prorockiego w Kościele. Autor nie zawęża jednak swych obserwacji tylko do eklezjologii i zagadnień związanych z proroctwem, lecz prezentuje naukę Montana w jej szerokim kontekście, ukazując także okoliczności zewnętrzne, niepokoje, klęski oraz środowisko powstania i rozwoju montanizmu. Wszystko to napisane przystępnym językiem i w oparciu o analizy tekstów, jak i prezentację różnych hipotez prezentowanych przez wcześniejszych badaczy montanizmu. Aby jednak nie przechwalić publikacji, można odnotować występujące w niej literówki, które winny być usunięte na etapie korekty, a szczególnie tytuł rozdziału szóstego, który w nagłówku przez ponad czterdzieści stron (ss. 117-151) stwierdza, iż zajmujemy się montanizmem w Ameryce (sic!) łacińskiej. Nie wpływa to jednak na wartość merytoryczną książki, która wzbogaca polską bibliografię, dotyczącą wczesnochrześcijańskiej heterodoksji i rozwoju myśli teologicznej, a szczególnie roli proroków u początków Kościoła.

Ks. Marcin Wysocki - Olsztyn

\title{
Henryk PIETRAS SJ, Eschatologia Kościoła pierwszych czterech wieków, Myśl Teologiczna 55, Kraków 2007, Wydawnictwo WAM, ss. 154.
}

We wstępie do swego wykładu o eschatologii Joseph Ratzinger pisał: „Jako «naukę o rzeczach ostatecznych» osadzano eschatologię przez całe stulecia u końca wykładu teologii, gdzie wiodła spokojny żywot. Dziś, w historycznym kryzysie epoki, znalazła się w samym centrum myśli teologicznej» (Śmierć $i$ życie wieczne, Warszawa 2000, 12). Takie umiejscowienie eschatologii w sposób szczególny widoczne jest w zainteresowaniu zwykłych ludzi zagadnieniami eschatologicznymi i chęcią poszerzenia swej wiedzy w tym zakresie, naprzeciw czemu starają się wychodzić współcześni teologowie. W ostatnich latach to zainteresowanie eschatologią widoczne jest także w ukazujących się na polskim rynku wydawniczym publikacjach. Poza wspomnianą powyżej, klasyczną już, wznowioną pozycją obecnego papieża, należy odnotować: J. Finkenzeller, Eschatologia. Podręcznik teologii dogmatycznej, tłum. W. Szymona, Kraków 2000; B. Sesboüé, Zmartwychwstanie i życie. Krótki traktat o rzeczach ostatecznych, tłum. M. Żerańska, Poznań 2002; F.J. Noc- 
ke, Eschatologia, tłum. W. Borowski, Sandomierz 2003; T.D. Łukaszuk, Ostateczny los człowieka $i$ świata $w$ świetle wiary katolickiej. Zarys eschatologii katolickiej, Kraków 2006; czy też trylogię Z. Kijasa, Czyściec - niebo - piekło, Kraków 1999-2002. Wszystkie te pozycje, będące w zamyśle całościowymi podręcznikami eschatologii, z konieczności traktują bardzo pobieżnie kolejne okresy kształtowania się dogmatu eschatologicznego i jedynie w zarysie przedstawiają niektóre kwestie szczegółowe. Promykiem nadziei na szczegółowe rozważania kwestii eschatologicznych w różnych okresach dziejów teologii stała się książka o. Augustyna Jankowskiego Eschatologia Nowego Testamen$t u$, której drugie wydanie, poprawione i uzupełnione, ukazało się w ostatnim czasie w Wydawnictwie WAM (Kraków 2006). Naturalną kontynuacją eschatologii biblijnej winno być przedstawienie rozwoju dogmatu eschatologicznego w okresie patrystycznym, szczególnie pierwszych wieków, co też dokonało się poprzez publikację książki H. Pietrasa Eschatologia Kościoła pierwszych czterech wieków.

Książka ta składa się z dziewięciu rozdziałów: w pierwszym (ss. 7-23) Autor przedstawia eschatologię żydowską w czasach Jezusa ukazując główne nurty, które stanowiły treść jej refleksji - nagrodę po śmierci i oczekiwanie na Mesjasza; rozdział drugi (ss. 24-30) przedstawia „Pierwszy millenaryzm według Apokalipsy św. Jana (Ap 20)", w rozdziale trzecim zatytułowanym , «Już i jeszcze nie» według Ojców Apostolskich" (ss. 31-41) Autor ukazuje problematykę zbawienia wybranych, modlitwy za zmarłych oraz wiecznego szabatu w pismach poapostolskiego pokolenia pisarzy chrześcijańskich, rozdział czwarty „Zstąpienie do piekieł” (ss. 42-51) wprowadza w prawdę o zstąpieniu Jezusa do otchłani poprzez analizę świadectw biblijnych, apokryfów i starożytnych pisarzy chrześcijańskich; w piątym rozdziale zatytułowanym: „Życie po śmierci a dualizm antropologiczny" (ss. 52-62) H. Pietras przedstawia koncepcje eschatologiczne, które ukształtowały się w nawiązaniu do greckiej koncepcji nieśmiertelnej duszy i śmiertelnego ciała oraz omawia apologetów II wieku (Pseudo-Justyn, Atenagoras) i Ireneusza z Lyonu. Rozdział szósty „Drugi millenaryzm" (ss. 63-82) poświęcony jest millenarystycznym poglądom Ireneusza z Lyonu i Tertuliana. „Tematy orygenesowskie” są tematyką siódmego rozdziału (ss. 83-108) omawianej dysertacji. Autor przedstawia w nim przekonania i hipotezy Orygenesa, grupując je wokół podstawowych tematów: „Krytyka materializmu”, ,Pierwsze zmartwychwstanie”, „Szkoła dusz”, ,,Seria światów”, „Sąd”, „Drugie zmartwychwstanie”, „Apokatastasis”. W rozdziale ósmym Autor omawia „Powszechne zbawienie według Grzegorza z Nyssy” (ss. 109-116) skupiając się na naturze krainy umarłych i apokatastazie w nauczaniu tego przedstawiciela Ojców Kapadockich. Ostatni dziewiąty rozdział „Augustyn z Hippony (354-430) i zbawienie przeznaczonych” (ss. 117-132) poświęcony jest eschatologii św. Augustyna, który ,wywarł poważny wpływ na cały późniejszy rozwój teologii na Zachodzie". Autor omawia w nim zagadnie- 
nie millenaryzmu, zmartwychwstania ciała, losu potępionych, niemożliwości apokatastazy i najwyższego szczęścia, które będzie udziałem tych, którzy będą mogli widzieć Boga oraz problem zbawienia nieochrzczonych. Książka ta zawiera ponadto wprowadzenie (ss. 5-6), zakończenie (ss. 133-135), indeksy biblijny i cytowanych źródeł (ss. 148-152) oraz bibliografię (ss. 136-147) podzieloną na dwie części: źródła i opracowania, opatrzoną w drugiej części komentarzami Autora do niektórych publikacji.

Używając słownictwa Autora, a właściwie cytowanych przez niego postaci, trzeba spojrzeć na niniejszą publikację w kategoriach „plusów pozytywnych i plusów negatywnych" (s. 76). Do niewątpliwych plusów pozytywnych należy już sam fakt, że po raz pierwszy została oddana do rąk polskich czytelników pozycja omawiająca rozwój doktryny eschatologicznej w pierwszych wiekach chrześcijaństwa, nadto pozycja napisana z charakterystyczną dla $\mathrm{H}$. Pietrasa elokwencją i humorem oraz nie mniej specyficzną cechą, jaką jest stawianie przez niego wywrotowych hipotez oraz proponowanie nowatorskich rozwiązań. Wydaje się, że Autor skupia się często na dyskusjach i dywagacjach, które nie dotyczą bezpośrednio tematyki książki, ale są za to nośnymi i wywołującymi dyskusje zagadnieniami, swoistym, żeby użyć popularnego powiedzenia, włożeniem kija w mrowisko. Autor stawia problem, wywołuje jakby do odpowiedzi, sygnalizuje wątpliwość i pozostawia z nią czytelnika, prowokuje, ale nie daje odpowiedzi, czego należałoby się spodziewać po książce pretendującej do miana podręcznika eschatologii pierwszych wieków. I to każe nam przejść do plusów negatywnych. Autor bowiem nakazuje czytelnikowi na słowo wierzyć w hipotezy, które stawia. Taką główną hipotezą, która wydaje się być przewodnim motywem książki, jest twierdzenie sformułowane na stronie 25, gdzie Autor pisze: ,aż do otrzymania dowodów przeciwnych - jestem zwolennikiem hipotezy, że Ewangelie powstały jako autorskie programy na użytek katechumenatu", gdy tymczasem we współczesnej biblistyce takie twierdzenie trudne byłoby do utrzymania. Taka hipoteza bowiem została sformułowana na potrzeby duszpasterskie przez kardynała C.M. Martiniego tylko odnośnie Ewangelii według św. Marka i trudno odnosić to twierdzenie do innych Ewangelii, pism nowotestamentalnych i twórczości Ojców Kościoła (por. C.M. Martini, Być z Jezusem, Kraków 1997; K. Wąs, Uwierzyć Jezusowi. Rekolekcje ze św. Markiem, Kraków 2004; J. Kochel, Katecheza ewangelizacyjna w nauczaniu pastoralnym C.M. Kard. Martiniego, Opole 1999), tym bardziej, że nie przedstawia na to wystarczających dowodów. Wydaje się, że o. Pietras przejął się zbytnio dyskusjami z B. Górką i duch neokatechumenatu za bardzo zaciążył na omawianej pozycji (zob. s. 25, przypis 24). Tematyka chrztu i katechumenatu wydaje się w niniejszej pozycji podstawową kategorią hermetyczną, a głównym problemem eschatologii pierwszych czterech wieków zdaje się być problem, czy ochrzczeni będą zbawieni czy też nie, choć przecież wątek ten w rzeczywistości nie stanowił centrum eschatologicznych dyskusji. Takie ukierunkowanie 
rozważań wydaje się wpływać na fakt, że Autor pomija wielu Ojców Kościoła. O ile do czasów Orygenesa - któremu poświęcony rozdział siódmy jest nota bene najlepszą częścią prezentowanej pozycji, ukazującą poglądy Aleksandryjczyka w sposób całościowy z ukazaniem najważniejszych elementów oraz dobrą analizą i doborem tekstów, jako że o. Pietras jest jednym z wybitnych znawców Orygenesa - nasz Autor przedstawia szerokie spektrum pisarzy wczesnochrześcijańskich i tekstów, o tyle następne dwa wieki potraktowane są trochę „po macoszemu”. Aż się prosi o przedstawienie poglądów na ten temat Jana Chryzostoma i Metodego z Olimpu. Omówienie tylko Grzegorza z Nyssy i Augustyna pozostawia pewien niedosyt. Na szczęście sam Autor zauważa we wprowadzeniu, że ,wybór tematów z pewnością jest subiektywny i wielu Czytelników zauważy brak czegoś, co by ich bardziej interesowało. Trudno. W każdym razie każdy z poruszonych tematów próbuję udokumentować cytatami, czasem nawet obszernymi, gdyż nie chcę, by Czytelnik musiał mi wierzyć na słowo" (s. 5). I rzeczywiście Autor wywiązał się ze swoich założeń. Liczne cytaty są z pewnością dużym plusem pozytywnym tej książki, ale wydaje się, że mogłoby się też znaleźć miejsce na głębszą analizę filologiczną oraz ukazanie terminów, którymi oddają rzeczywistości eschatologiczne pisarze wczesnochrześcijańscy. Kwestią otwartą pozostaje także to, czy nie warto by było sięgnąć do większej ilości dzieł nieprzetłumaczonych na język polski, które wniosłyby z pewnością dużo więcej do omawianego tematu, a jednocześnie przybliżyłyby polskim czytelnikom bogactwo jeszcze nietłumaczonych pozycji. Drobnostką wydają się być także liczne literówki, nieuniknione prawdopodobnie w toku druku (por. s. 18, 33, 42, 70, 117) oraz błąd w numeracji cytatów biblijnych (s. 115). Zagadką pozostaje także klucz, według którego Autor dokonał podziału treści książki - czy jest to klucz przedmiotowy czy też autorski, chronologiczny: w pierwszej bowiem części na przykład stosuje najpierw kryterium dzieł, aby potem przejść nagle do kryterium podziału treści według zagadnienia kary i nagrody (ss. 7-23). Wyjaśnić też należy, czy rzeczywiście Męczeństwo Perpetuy i Felicyty przynależy do pism Ojców Apostolskich, jak sugeruje to Autor, i czy rok 200 nie jest za wczesny na przyłączenie się Tertuliana do montanistów (ss. 34-37 i 74).

Należy docenić wkład, jaki wnosi publikacja H. Pietrasa - Eschatologia Kościoła pierwszych czterech wieków w polskie piśmiennictwo teologiczne i w przybliżanie polskim czytelnikom twórczości Ojców Kościoła i rozwoju dogmatu eschatologicznego. A że cechą chrześcijańskiej eschatologii jest nadzieja, dlatego też jestem jej pełen, że za kilka lat ukaże się drugie wydanie omawianej pozycji - uporządkowane i przemyślane jeszcze raz przez Autora - podobnie jak się to stało ze wznowioną ostatnio jego książką Początki teologii Kościoła.

Ks. Marcin Wysocki - Olsztyn 